\title{
Хорологическая структура
}

\section{природно-очаговых инфекций в азиатской части Российской Федерации}

\author{
A.K. Носков (noskov-epid@mail.ru), М.Б. Шаракшанов, \\ А.Я. Никитин, Е.А. Вершинин, С.В. Балахонов
}

ФКУЗ «Иркутский научно-исслеАовательский противочумный институт» РоспотребнаАзора

\section{Резюме}

На основании физико-климатических особенностей проведено деление азиатской части Российской Федерации на южную и северную зоны. Проведен ретроспективный анализ заболеваемости населения природно-очаговыми инфекционными болезнями, установлен спектр нозологических форм и интенсивность эпидемического процесса в каждой из выделенных зон. Эпидемические проявления природно-очаговых болезней наиболее выражены в субъектах, относящихся к южной зоне, с доминированием инфекций, передающихся иксодовыми клещами. В северной зоне на долю местных случаев природно-очаговых инфекций приходится 57,1\%. При чем заболеваемость регистрировалась только среди населения Ямало-Ненецкого автономного округа, и только нетрансмиссивными инфекциями: ГлПС и бешенство.

Ключевые слова: азиатская часть Российской Федерации, природно-очаговые инфекции, эпидемиологическая ситуация

\section{Chorological Structure of natural focal infections in the Asian part of the Russian Federation}

A.K. Noskov (noskov-epid@mail.ru), M.B. Sharakshanov, A.Ya. Nikitin, E.A. Vershinin,

S.V. Balakhonov

Federal Budgetary Healthcare Facility «Irkutsk Antiplague Research Institute» of Federal Service on Customers' Rights Protection and Human Well-Being Surveillance

\section{Abstract}

Division of the Asian part of the Russian Federation into southern and northern zones was implemented on the basis of physical-climatic features. The retrospective analysis of the natural focal infectious diseases in humans was carried out. Spectrum of nosological forms and epidemic process intensity in each of the evolved zones were established. Epidemic manifestations were the most expressed in the Subjects belonging to the southern zone, with domination of the Ixodes tick-borne infections. In northern zone natural focal infections included $57,1 \%$ of local cases, they were registered only in the population of Yamal-Nenets Autonomous Okrug (District), and barely nontransmissible infections: hemorrhagic fever with renal syndrome and rabies.

Key words: the Asian part of the Russian Federation, natural focal infection, an epidemiological condition

\section{Введение}

Российская Федерация (РФ) является крупнейшей по площади страной мира, западные территории которой располагаются в европейской, а восточные - в азиатской частях Евразии.

Азиатская часть (АЧ) РФ простирается от Уральских гор до Камчатки. В ее состав входят 24 субъекта федерации: девять - Дальневосточного; 12 - Сибирского и три - Уральского федеральных округов. Площадь региона составляет более 14,5 млн км², и занимает около 77 \% площади РФ. Территория АЧ РФ характеризуется разнообразными природными и климатическими условиями. Ландшафтно-географические и социально-экономические особенности отдельных частей региона оказывают значительное влияние на распределение населения, ведение им культурной и хозяйственной деятельности, а также на заселенность основными носителями и переносчиками инфекционных болезней, что в совокупности обуславливает интенсивность эпидемического проявления природно-очаговых инфекций (ПОИ).

Цель работы - анализ хорологической структуры природно-очаговых инфекций в азиатской части Российской Федерации в 2009 - 2015 годах.

\section{Материалы и методы}

Анализ заболеваемости поИ в субъектах азиатской части РФ в 2009 - 2015 годах проведен по данным формы № 2 государственной статистической отчетности "Сведения об инфекционных и паразитарных заболеваниях" ФБУЗ "Федеральный центр гигиены и эпидемиологии" Роспотребнадзора. В работе использованы сведения, поступающие в Референс-центр по мониторингу природно-очаговых болезней бактериальной и вирусной этиологии ФКУЗ “Иркутский научно-исследовательский противочумный институт» Роспотребнадзора.

Из группы ПОИ в анализ не вошли сведения о заболеваемости населения псевдотуберкулезом и кишечным иерсиниозом, так как заражение 
человека в основном происходит алиментарным путем и необходимым условием является накопление возбудителя в контаминированных пищевых продуктах.

Статистическая обработка проведена путем расчета величины средней и ее стандартной ошибки для выборок с альтернативной вариацией. КАКИХ?

\section{Результаты и обсуждение}

На основании анализа пространственных причинно-следственных связей между характерными географическими различиями территории и распределением по ней макро- и микроорганизмов (хорологическая концепция Альфреда Геттнера, 1927), нами проведено условное административно-территориальное деление АЧ РФ на две зоны: севернее (северная зона) и южнее (южная зона) $55^{\circ}$ с.ш. (рис. 1$)$.

В основу определения границ деления АЧ РФ на условные зоны легли физико-географические критерии. Граница примерно соответствует изолинии, где сумма среднесуточных температур в субъекте, за вегетационный период выше $10^{\circ} \mathrm{C}$. На большей части административных территорий, лежащих севернее условной границы, отсутствует широкое развитие сельского хозяйства, т.е. прежде всего стабильное выращивание зерновых культур как основы земледелия и скотоводства, а экстремальные условия формируют своеобразную фауну мелких млекопитающих и эктопаразитов - носителей и переносчиков патогенных для человека возбудителей ПОИ.

Климат АЧ РФ отличается особой контрастностью и является более суровым в сравнении с европейской частью страны. Северная зона располагается в арктическом и субарктическом поясах, представленных климатом субарктических и арктических пустынь и тундр. Южная зона находится в умеренном поясе, климат - от умеренного до резко континентального и муссонного на юге Дальнего Востока. Ввиду физико-климатических различий ландшафтное разнообразие северных территорий АЧ РФ гораздо беднее южных. Территории северной зоны - это сменяющие друг друга различные тундровые и таежные ландшафты, на побережье Северного Ледовитого океана - полярные, гляциально-нивальные и арктические пустыни. Тогда как в южной зоне наблюдается разнообразие

Рисунок 1.

Районирование территории АЧ РФ на северную и южную зоны

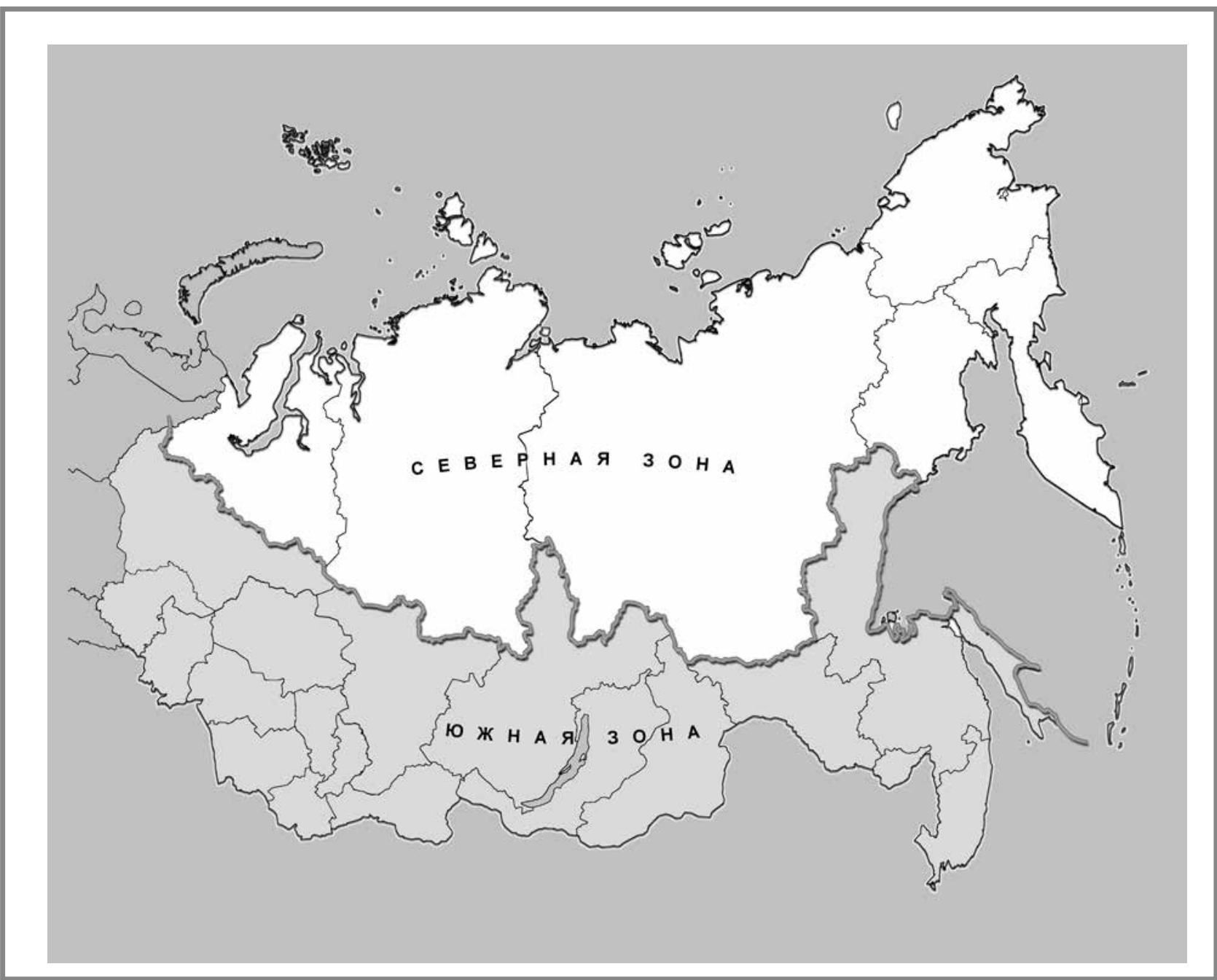


Рисунок 2.

Доля отдельных ПОИ (\%) в спектре нозологических форм регистрируемых по южной (А) и северной (Б) зонам Азиатской части РФ в 2009 - 2015 годах

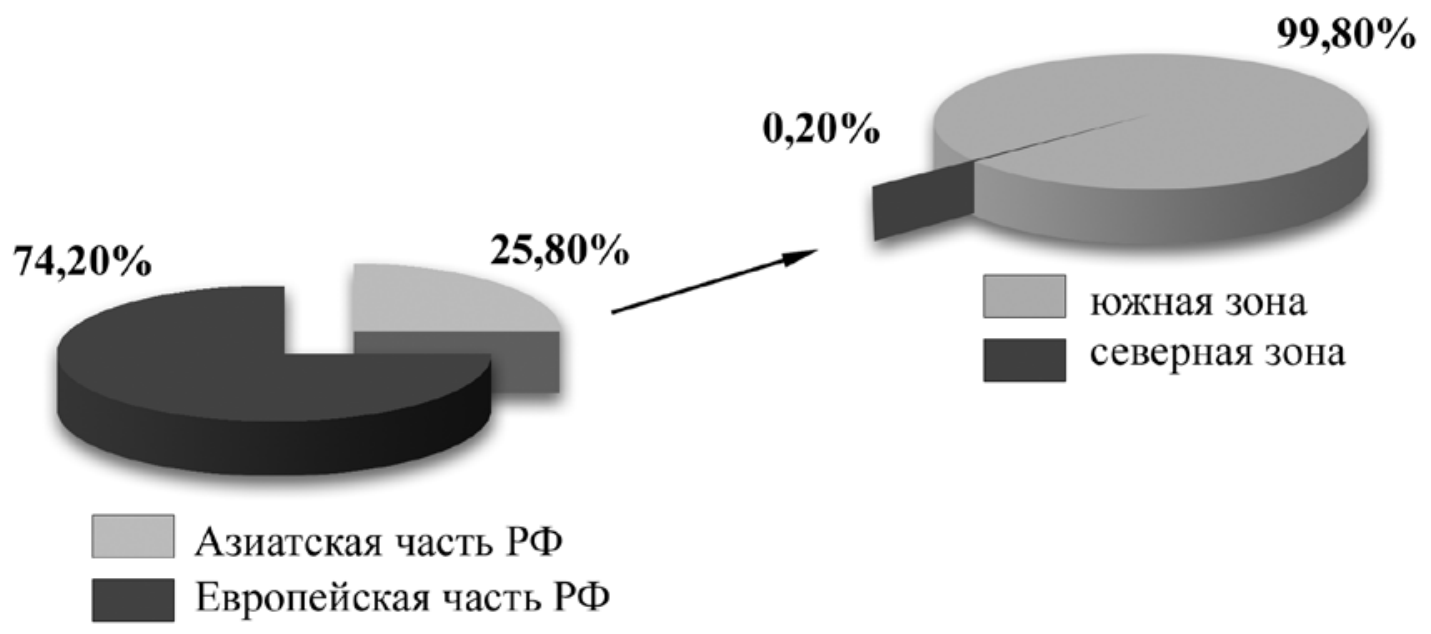

и мозаичность ландшафтов с чередованием различных широтно-зональных равнинных и горных областей. Влажность варьирует от избыточной на севере, до недостаточной на юге [1 - 3].

В Северную зону АЧ РФ вошли большая часть районов Крайнего Севера и приравненные к ним местности с экстремальными условиями проживания (Республика Саха (Якутия), Камчатский край, Магаданская область, Чукотский и Ямало-Ненецкий автономные округа).

Южная зона включает Республики Алтай, Бурятия, Тыва и Хакасия, Алтайский, Забайкальский, Приморский, Хабаровский края, Амурскую, Иркутскую, Кемеровскую, Новосибирскую, Омскую, Сахалинскую, Томскую, Тюменскую области, Еврейскую автономную область и Ханты-Мансийский автономный округ. Как отмечено выше, климатические особенности южной зоны позволяют говорить о более благоприятных условиях для проживания и ведения хозяйственной деятельности.

Красноярский край, границы которого протянулись с юга до севера АЧ РФ, зонируется с выделением Эвенкийского, Таймырского (Долгано-Ненецкого) и Туруханского муниципальных районов, формирующих единую административную территорию северной зоны АЧ РФ.

Распределение населения АЧ РФ имеет неравномерный характер. В среднем в 2009 - 2015 годах на территории южной зоны проживало около 27 млн человек (93,1\% от общей численности населения АЧ РФ), при средней плотности 3,5 чел./ км². В основном жители концентрируются вдоль Транссибирской железнодорожной магистрали, а также вблизи крупных городов и промышленных центров Кемеровской $(28,4$ чел./км²), Новосибирской (15,5 чел./км²), Омской (14,0 чел./км²) областей, Алтайского (14,2 чел./км²) и Приморского (11,7 чел./км²) краев [4].

Средняя численность населения северной зоны составляет около двух млн человек (0,3 чел./км²). Однако для этой зоны показатель средней плотности населения носит условный характер в связи с "очаговым типом" заселения - редкие локальные поселения с относительно высокой плотностью. Это объясняется как суровым климатом с неблагоприятными для жизнедеятельности человека условиями, так и экономическими причинами. Кроме относительно крупных населенных пунктов люди концентрируются вблизи разрабатываемых месторождений полезных ископаемых, в районах их переработки и транспортных узлов. Коренные малочисленные народы Севера (менее 50 тыс. человек) проживают на территориях традиционного расселения своих предков, сохраняя соответствующий образ жизни, хозяйствования и промыслов. К хозяйственным видам их деятельности относятся: оленеводство, охота, рыболовство, собирательство и др.

Географическое расположение и климатические условия северной зоны АЧ РФ оказывают существенное влияние на распространение, численность и видовой состав мелких млекопитающих - основных носителей возбудителей ПОИ, с тенденцией к увеличению их разнообразия по направлению с севера на юг. В северной зоне обитают зверьки 23 видов: от двух видов - в пустынно-арктическом поясе, до 16 - в поясах северотаежном и горных лесов редуцированного развития. Для сравнения в южной зоне АЧ РФ установлено обитание 69 видов мелких млекопитающих [5]. Аналогичное влияние оказывается на видовое и численное разнообразие членистоногих - переносчиков возбудителей многих ПоИ, что обуславливает их крайне 
Таблица 1.

Доля отдельных нозологических форм в структуре поИ различных частей территории РФ за 2009-2015 гr.

\begin{tabular}{|c|c|c|c|c|c|}
\hline \multirow{2}{*}{\multicolumn{2}{|c|}{ Нозологическая форма }} & \multirow{3}{*}{$\begin{array}{c}\begin{array}{c}\text { Европейская часть } \\
\text { PФ }\end{array} \\
104503\end{array}$} & \multicolumn{3}{|c|}{ Азиатская часть РФ } \\
\hline & & & \multirow{2}{*}{$\begin{array}{l}\text { Bcero } \\
36412\end{array}$} & \multirow{2}{*}{$\begin{array}{c}\text { Южная зона } \\
36356\end{array}$} & \multirow{2}{*}{$\frac{\text { Северная зона }}{56}$} \\
\hline Всего пОИ, & абс. & & & & \\
\hline в том числе: & $\%$ & 100 & 100 & 100 & 100 \\
\hline \multirow{2}{*}{$\begin{array}{l}\text { ПОИ, обусловленные } \\
\text { экстраординарными } \\
\text { событиями* }\end{array}$} & абс. & н.д. & 1039 & 1039 & 0 \\
\hline & $\%$ & - & 2,9 & 2,9 & 0 \\
\hline \multirow{2}{*}{ Туляремия } & абс. & 352 & 131 & 131 & 0 \\
\hline & $\%$ & 0,3 & 0,4 & 0,4 & 0 \\
\hline \multirow{2}{*}{ ГлПС } & абс. & 50666 & 756 & 724 & 32 \\
\hline & $\%$ & 48,4 & 2,1 & 1,99 & 57,1 \\
\hline \multirow{2}{*}{ Лептоспирозы } & абс. & 1939 & 81 & 81 & 0 \\
\hline & $\%$ & 1,9 & 0,2 & 0,2 & 0 \\
\hline \multirow{2}{*}{ Бешенство } & абс. & 56 & 5 & 4 & 1 \\
\hline & $\%$ & 0,1 & 0,01 & 0,01 & 1,8 \\
\hline \multirow{2}{*}{ КВЭ } & абс. & 9023 & 10558 & 10555 & 3 \\
\hline & $\%$ & 8,6 & 28,99 & 29,0 & 5,4 \\
\hline \multirow{2}{*}{ ИКБ } & абс. & 41974 & 12579 & 12559 & 20 \\
\hline & $\%$ & 40,2 & 34,5 & 34,5 & 35,7 \\
\hline \multirow{2}{*}{ KP } & абс. & 89 & 11034 & 11034 & 0 \\
\hline & $\%$ & 0,1 & 30,3 & 30,3 & 0 \\
\hline \multirow{2}{*}{ МЭЧ } & абс. & 50 & 44 & 44 & 0 \\
\hline & $\%$ & 0,1 & 0,1 & 0,1 & 0 \\
\hline \multirow{2}{*}{ ГАЧ } & абс. & 354 & 185 & 185 & 0 \\
\hline & $\%$ & 0,3 & 0,5 & 0,5 & 0 \\
\hline
\end{tabular}

Примечание: ^Республика Алтай (два случая бубонной чумы в 2014 и 2015 гг.); ХМАО (1005 случаев при вспышке туляремии в 2013 г.); Еврейская АО (19 случаев ГЛПС в 2014 г.); Хабаровский край (10 случаев туляремии в 2015 г. и три лептоспироза в 2014 2015 гг.)

не равномерное распределение по территории АЧ РФ. В связи с тем, что многочисленные представители гнуса в северной зоне не формируют риски для эпидемического проявления “комариных" инфекций, для АЧ РФ наиболее характерны болезни, возбудителей которых передают представители семейства иксодид [6]. Следует отметить, что территории северной зоны АЧ РФ практически свободны от иксодовых клещей, мозаичные поселения которых встречаются лишь вблизи ее южной границы (между 55 и 63 параллелями). Их видовое богатство и численность постепенно увеличиваются в южном направлении. Зона тайги характеризуется абсолютным доминированием Ixodes persulcatus (таежного клеща). В подтаежной зоне также наблюдается преобладание этого вида, а представители родов Haemaphysalis и Dermacentor встречаются лишь на локальных участках с благоприятными для них условиями обитания, где могут достигать высокой численности. При этом в зоне смешанных и широколиственных лесов, то есть в южной зоне, практически повсеместно наблюдается высокая и очень высокая численность иксодид [7].

Результаты многолетних исследований, проведенных в различные исторические промежутки времени, свидетельствуют о циркуляции на территории АЧ РФ широкого спектра патогенных для человека возбудителей ПОИ, в том числе относящихся к группе вирусов серокомплекса Калифорнийского энцефалита (Инко, Тягиня, Зайца-беляка), альфавирусов и др. [8 - 10]. Однако среди населения случаев заболеваний, вызванных этой группой вирусов, не зарегистрировано. Это может быть связано как с отсутствием соответствующей настороженности среди медицинских работников, 
Рисунок 3.

Доля (\%) нозологических форм ПОИ, зарегистрированных в 2009 - 2015 годах:

в Европейской и Азиатской частях РФ (А); южной и северной зонах АЧ РФ (Б);

вызванных экстраординарными событиями на территории южной зоны АЧ РФ (В)

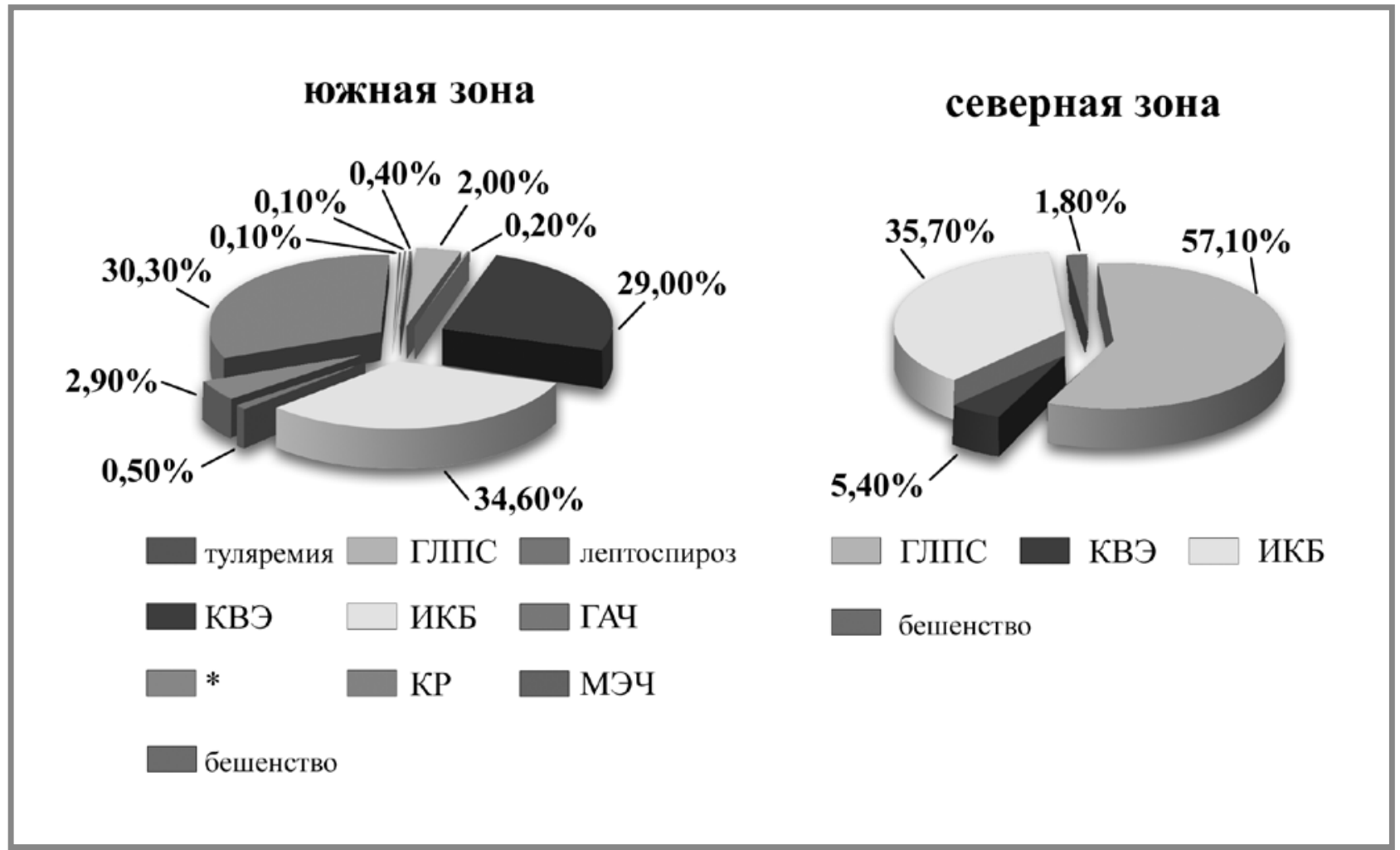

Примечание: ПОИ, обусловленные экстраординарными событиями: два случая бубонной чумы (Республика Алтай, 2014,2015 гг.), 1005 - туляремии (ХМАО, 2013 г.), 19 - ГЛПС (Еврейская АО, 2014 г.), 10 - туляремии (Хабаровский край, 2015 г.), три - лептоспироза (Хабаровский край, 2014, 2015 гг.)

так и с ограниченными возможностями лабораторной диагностики.

По официальным данным за 2009 - 2015 годы, на территориях субъектов АЧ РФ зарегистрировано 36412 случаев ПОИ - 25,8 \% от общего числа по стране (рис. 2. А).

В отдельных субъектах АЧ РФ из группы ПОИ среди населения регистрируются инфекции, передающиеся исключительно иксодовыми клещами [11, 12], а также геморрагическая лихорадка с почечным синдромом (ГЛПС) [13, 14], лептоспирозы [15 - 18], чума, туляремия и бешенство. Причем три последние инфекции могут провоцировать чрезвычайные ситуации эпидемиологического характера [19 - 22].

За анализируемый период эпидемиологическая ситуация по ПОИ в АЧ РФ характеризовалась рядом особенностей. Первая - в структуре ПОИ преобладали инфекции, передаваемые иксодовыми клещами. На эту группу болезней пришлось 94,5 \pm 0,12 \% (34 400 случаев) от всех ПоИ (табл. 1). Вторая в южной зоне АЧ РФ отмечались: вспышка туляремии на эндемичной территории Ханты-Мансийского АО, пострадало 1005 человек (2013 год); два случая бубонной чумы среди жителей Кош-Агачского района (Республика Алтай), располагающегося на территории Горно-Алтайского высокогорного природного очага чумы (2014 и 2015 годы). Необходимо отметить, что в 2016 году в Республике Алтай зарегистрирован еще один случай заболевания человека бубонной чумой. Третья особенность - на территории региона зарегистрирован ряд чрезвычайных ситуаций (ЧС) природного характера, существенно увеличивших риски эпидемического проявления инфекционных болезней, в том числе ПоИ, как непосредственно во время события, так и в краткосрочной перспективе [23, 24].

Наглядным примером влияния чС природного характера на динамику эпидемического процесса (даже с учетом цикличности последнего) является ситуация, сложившаяся на территориях Еврейской АО и Хабаровского края после катастрофического паводка в Приамурье 2013 году. Непосредственно во время ЧС своевременно и в должном объеме организованные и проведенные противоэпидемические (профилактические) мероприятия позволили избежать осложнений эпидемиологической ситуации с ПоИ на территориях, пострадавших в период паводка. Однако уже в 2014 году в Еврейской АО зарегистрировано 19 случаев ГЛПС, с интенсивным показателем заболеваемости 11,4 на 100 тыс. населения, что в 2,2 раза выше среднего многолетнего, а в Хабаровском крае 10 случаев туляремии на фоне отсутствия проявления этой нозоформы с 2005 года. 
Как уже говорилось выше, географические и климатические условия АЧ РФ определяют вид и распространенность носителей и переносчиков инфекционных болезней и, следовательно, активность природных очагов в разных зонах. В 2009 - 2015 годах в южной зоне зафиксировано 99,8 \% (36 356 случаев) ПОИ в АЧ РФ (рис. 2. Б). При этом в южной зоне ПОИ регистрировались ежегодно во всех 18 субъектах, а в северной - спорадически (лишь в трех случаях), причем 24 случая заболеваний (42,9 \%) связаны с инфицированием на эндемичных территориях, не входящих в эту зону.

Средний многолетний показатель заболеваемости ПОИ в субъектах, входящих в южную зону, составлял 19,7 \pm 0,26 на 100 тыс. населения. Спектр регистрируемых ПОИ представлен 10 нозологическими формами (рис. 3. А). За анализируемый период преобладали иксодовые клещевые боррелиозы (12 559 случаев, 34,5 \% от всех ПОИ в южной зоне), клещевой риккетсиоз (11 034 случая, 30,3 \%) и клещевой энцефалит (10 555 случаев, 29 \%). Доля этих нозологических форм в структуре ПоИ составила 93,9 \%, среди всех зарегистрированных ПоИ на территории субъектов южной зоны. Значительно реже диагностировали ГлПС (724 случая, 2 \%), туляремию (131 случай, 0,4 \%) и лептоспирозы (81 случай, 0,2 \%).

В северной зоне в 2009 - 2015 годах отмечено 56 случаев ПОИ (0,2 \%),Средний многолетний показатель составил 0,4 \pm 0,14 на 100 тыс. населения (см. табл. 1, рис. 3. Б). Основное количество ПоИ отмечено в Ямало-Ненецком АО - 50 случаев. Однако 18 из них (15 - ИКБ и три - КВЭ) связаны с присасыванием клещей при посещении людьми эндемичных по этим заболеваниям территорий других субъектов. В Республике Саха (Якутия) и Камчатском крае выявлено по три случая ПоИ, все завозного характера. Необходимо отметить, что в Магаданской области, Чукотском АO, Таймырском (Долгано-Ненецкий), Эвенкийском и Туруханском муниципальных районах Красноярского края, входящих в северную зону, поИ за семилетний период не регистрировались.

Несмотря на низкую заболеваемость ПоИ людей в северной зоне АЧ РФ, на ее территориях име- ются определенные особенности, увеличивающие риски эпидемического проявления этой группы болезней. Точечное заселение обширных суровых территорий способствует концентрации населения на ограниченном пространстве и, как следствие, при наличии источника инфекции возможности реализации различных путей передачи возбудителей ПОИ. Широкое использование экспедиционных и вахтовых форм труда, сезонная внутренняя и трансграничная миграция местного населения в период короткого северного лета увеличивают риск заноса различных ПоИ с эндемичных территорий, сопровождающийся возможностью формирования эпидемических очагов.

\section{Выводы}

1. Комплексная оценка ландшафтно-географических, климатических и социально-экономических особенностей азиатской части РФ позволила условно разделить ее на южную и северную зоны. Выделенные зоны отличаются видовой структурой, численностью носителей и переносчиков возбудителей ПОИ, а также напряженностью природных очагов и интенсивностью эпидемического процесса.

2. Эпидемический процесс наиболее выражен в субъектах, относящихся к южной зоне, на которые пришлось 99,8 \% зарегистрированных случаев ПОИ. В структуре нозологических форм этой зоны в 2009 - 2015 годах доминировали инфекции, передающиеся иксодовыми клещами (94,5\%).

3. В субъектах северной зоны местные случаи природно-очаговых инфекций составляли 57,1 \% (32 случая). Заболеваемость поИ регистрировалась только среди населения ЯмалоНенецкого автономного округа и только нетрансмиссивными инфекциями: ГлПс (31 случай) и бешенство (один случай). Остальные 42,9 \% случаев ПоИ, зарегистрированных в трех субъектах северной зоны, относились к инфекциям, передающимся иксодовыми клещами, и были обусловлены заражением людей на эндемичных территориях за ее пределами северной зоны.

\section{Литература}

1. Кротов В.А., Помус М.И., Рихтер Г.Д., Сочава В.Б. Восточная Сибирь. Экономико-географическая характеристика. Москва: Географгиз; 1963.

2. Конева И.В., Батуев А.Р., Лопаткин Д.А. Картографирование нозоэкосистем Азиатской России (пояснительные материалы к карте). Иркутск: Издательство Институт географии им. В.Б. Сочавы СО РАН; 2012.

3. Рихтер Г.Д. Дальний Восток (Физико-геграфическая характеристика). Москва: Издательство Академии наук СССР; 1961 -

4. Бугакова Н.С., Гельвановский М.И., Глисин Ф.Ф., Горячева И.П., Гохберг Л.М., Житков В.Б. и др. Регионы России. Социально-экономические показатели. Статистический сборник. Г.К. Оксенойт, ред. Москва: Росстат; 2015.

5. Конева И.В. Разработка специального содержания карты населения грызунов и зайцеобразных Азиатской России для нозоэкологических исследований. Картографирование населения грызунов и зайцеобразных Азиатской России. А.В. Белова, ред. Иркутск: Издательство «Восточно-Сибирская правда»; 1988.

6. Злобин В.И. Природно-очаговые трансмиссивные инфекции Сибири и Дальнего Востока. Журнал инфекционной патологии. $1999 ; 2$ - 3: 3 - 8.

7. Вершинина Т.А., Конева И.В., Байбородин В.Н. Типы населения иксодовых клещей Азиатской России. Опыт создания карты иксодовых клещей Азиатской России. Б.Б. Прохоров, ред. Иркутск: 1974.

8. Львов Д.К., Дерябин П.Г., Аристова В.А., Бутенко А.М., Галкина И.В., Громашевский В.Л. и др. Атлас распространения возбудителей природно-очаговых вирусных инфекций на территории Российской Федерации. Москва: Издательство НПЦ ТМГ МЗ РФ; 2001.

9. Чапоргина Е.А. Горин О.З., Львов С.Д., Феоктистов А.З., Бутенко А.М., Трухина А.Г. и др. Распространение арбовирусов в Прибайкалье. Журнал инфекционной патологии. 1998; 5 (2 - 3): 54 - 59. 
10. Егоров И.Я., Марамович А.С., Ботвинкин А.Д. Эпиднадзор за особо опасными и природно-очаговыми инфекциями в условиях Крайнего Севера. Якутск: 2000.

11. Никитин А.Я., Носков А.К., Андаев Е.И., Пакскина Н.Д., Яцменко Е.В., Веригина Е.В. и др. Эпидемиологическая ситуация по клещевому вирусному энцефалиту в Российской Федерации в 2015 г. и прогноз на 2016 г. Проблемы особо опасных инфекций. $2016 ; 1: 40$ - 43.

12. Носков А.К., Ильин В.П., Андаев Е.И., Пакскина Н.Д., Веригина Е.В., Балахонов С.В. Заболеваемость клещевым вирусным энцефалитом в Российской Федерации и по федеральным округам в 2009 - 2013 гг., эпидемиологическая ситуация в 2014 г. и прогноз на 2015 г. Проблемы особо опасных инфекций. 2015; 1: $46-50$

13. Яшина Л.Н., Иванов Л.И., Слонова Р.А., Компанец Г.Г., Гуторов В.В., Кушнарева Т.В. и др. Хантавирусы, циркулирующие в полевках Мicrotus fortis и Microtus maximowiczii. Тихоокеанский медицинский журнал. 2008; 2: 47 - 49.

14. Кушнарева Т.В. Эпизоотологический потенциал мышевидных грызунов в природных очагах хантавирусной инфекции и его эпидемиологическое значение. Тихоокеанский медицинский журнал. 2008; 2: 50 - 52.

15. Макеев С.М., Марамович А.С., Носков А.К., Чернявский В.Ф., Кондаков А.А. Эпидемиолого-эпизоотологическое районирование территории и профилактика лептоспирозов в Дальневосточном федеральном округе. Проблемы особо опасных инфекций. 2007; 2: $24-27$.

16. Бренева Н.В., Носков А.К., Киселева Е.Ю., Шаракшанов М.Б., Борисов С.А., Курганова О.П. и др. Анализ ситуации по лептоспирозам в Приамурье. Опыт работы в зоне затопления в 2013 г. и прогноз на 2014 г. Проблемы особо опасных инфекций. $2014 ; 1: 94$ - 97.

17. Бренева Н.В., Киселева Е.Ю., Макеев С.М. Проблемы эпидемиологии и диагностики лептоспирозов в Сибири и на Дальнем Востоке. Журнал микробиологии, эпидемиологии и иммунобиологии. 2012; 3: 96 - 102.

18. Шаракшанов М.Б., Бренёва Н.В., Носков А.К., Киселева Е.Ю., Высочина Н.П., Мусатов Ю.С. и др. Современная ситуация по лептоспирозам на юге Дальнего Востока. Эпидемиология и инфекционные болезни. Актуальные вопросы. 2016; 4: 9 - 15.

19. Балахонов С.В., Попова А.Ю., Мищенко А.И., Михайлов Е.П., Ежлова Е.Б., Демина Ю.В. и др. Случай заболевания человека чумой в Кош-Агачском районе Республики Алтай в 2015 г. Сообщение 1. Клинико-эпидемиологические и эпизоотологические аспекты. Проблемы особо опасных инфекций. 2016; 1: $55-60$.

20. Кутырев В.В., Попова А.Ю., Ежлова Е.Б., Демина Ю.В., Пакскина Н.Д., Щучинов Л.В. и др. Заболевание человека чумой в Горно-Алтайском высокогорном природном очаге в 2014 г. Сообщение 1. Эпидемиологические и эпизоотологические особенности проявлений чумы в Горно-Алтайском высокогорном (Сайлюгемском) природном очаге чумы. Проблемы особо опасных инфекций. 2014; 4:9 - 16.

21. Мещерякова И.С., Добровольский А.А., Демидова Т.Н., Кормилицына М.И., Михайлова Т.В. Трансмиссивная эпидемическая вспышка туляремии в г. Ханты-Мансийске в 2013 году. Эпидемиология и вакцинопрофилактика. 2014; 5: 14 - 20.

22. Остапенко Н.А., Соловьева М.Г., Казачинин А.А., Козлова И.И., Файзуллина Н.М., Ежлова Е.Б. О вспышке туляремии среди населения Ханты-Мансийска и Ханты-Мансийского района в 2013 г. Проблемы особо опасных инфекций. 2015; 2: 28 - 32.

23. Обеспечение санитарно-эпидемиологического благополучия населения при ликвидации последствий наводнения на Дальнем Востоке. Под ред. Г.Г. Онищенко и С.В. Балахонова. Новосибирск: Наука-Центр; 2014.

24. Носков А.К., Балахонов С.В., Михайлов Л.М., Вишняков В.А., Куликалова Е.С., Мазепа А.В. и др. Эпидемиологическая ситуация по природно очаговым инфекционным болезням на территориях Сибири и Дальнего Востока, пострадавших от стихийных бедствий в 2013-2014 годах. Дальневосточный журнал инфекционной патологии. 2016; 30: 6 - 10.

\section{References}

1. Krotov V.A., Pomus M.I., Rikhter G.D., Sochava V.B. East Sibiria. Economic-geographical characteristics. Moscow: Geografgis; 1963 (in Russian).

2. Koneva I.V., Batuev A.R., Lopatkin D.A. Mapping of nosoecosystems of the Asian Russia (explanatory materials to the map). Irkutsk: Publishing house of V.B. Sochava Institute of Geography of the Siberian Branch of the Russian Academy of Sciences; 2012 (in Russian).

3. Rikhter G.D. The Far East (physical-geographical characteristics). Moscow: Publishing house of Academy of Sciences of the USSR; 1961 (in Russian).

4. Bugakova N.S., Gelvanovsky M.I., Glisin F.F., Goryacheva I.P., Gokhberg L.M., Zhitkov V.B. et al. Regions of Russia. Social-economic activities. Statistical compendium. Edit.: G.K. Oksenoit. Moscow: Rosstat; 2015 (in Russian).

5. Koneva I.V. Development of the special content of the map of the rodent and lagomorphs population in the Asian Russia to nosoecological investigations. Mapping of the the rodent and lagomorphs population in the Asian Russia. Edit.: A.V. Belov. Irkutsk: Publishing house "Vostochno-Sibirskaya Pravda»; 1988 (in Russian).

6. Zlobin V.I. Natural focal transmissible infections in Siberia and Far East. Infektsionnaya patologiya. [Journal of Infectious Diseases]. $1999 ; 2$ - 3: 3 - 8 (in Russian).

7. Vershinina T.A., Koneva I.V., Baiborodin V.N. Types of Ixodes tick population in the Asian Russia. Experience of creation of Ixodes tick map of the Asian Russia. Edit.: B.B. Prokhorov. Irkutsk: 1974 (in Russian).

8. Lvov D.K., Deryabin P.G., Aristova V.A., Butenko A.M., Galkina I.V., Gromashevsky V.L. et al. Atlas of dissemination of natural focal infection agents at the territory of the Russian Federation. Moscow; 2001 (in Russian).

9. Chaporgina E.A., Gorin O.Z., Lvov S.D., Feoktistov A.Z., Butenko A.M., Trukhina A.G., et al. Arbovirus dissemination in Fore-Baikal Territory. Zhurn. infektsionnoi patologii. [Journal of Infectious Diseases]. 1998; 5 (2 - 3): 54 - 59 (in Russian).

10. Egorov I.Ya., Maramovich A.S., Botvinkin A.D. Epidemiological surveillance for especially dangerous and natural focal infections at the Extreme North conditions. Yakutsk: 2000 (in Russian).

11. Nikitin A.Ya., Noskov A.K., Andaev E.I., Pakskina N.D., Yatsmenko E.V., Verigina E.V. et al. Epidemiological situation to tick-borne encephalitis virus in the Russian Federation in 2015 and the forecast for 2016. Probl. osobo opasnykh infektsii. [Problems of especially dangerous infections]. 2016; 1: 40 43 (in Russian).

12. Noskov A.K., Ilyin V.P., Andaev E.I., Pakskina N.D., Verigina E.V., Balakhonov S.V. Incidence rate of tick-borne encephalitis virus in the Russian Federation and in Federal Districts in 2009-2013, an epidemiological situation in 2014 and the forecast for 2015. Probl. osobo opasnykh infektsii. [Problems of especially dangerous infections]. 2015; 1: 46 - 50 (in Russian).

13. Yashina L.N., Ivanov L.I., Slonova R.A., Kompanets G.G., Gutorov V.V., Kushnareva T.V. et al. Hantaviruses circulating in Microtus fortis and Microtus maximowiczii voles. Tikhookeanskii meditsinskii zhurnal. [Pacific Medical Journal]. 2008; 2: 47 - 49 (in Russian).

14. Kushnareva T.V. Epizootological potential of murine rodents in the natural foci of Hanta virus infection and its epidemiological value. Tikhookeanskii meditsinskii zhurnal. [Pacific Medical Journal]. 2008;2: 50 - 52 (in Russian).

15. Makeev S.M., Maramovich A.S., Noskov A.K., Chernyavsky V.F., Kondakov A.A. Epidemiological-epizootological division into districts of territory and leptospiroses prevention measures in Far Eastern Federal District. Probl. osobo opasnykh infektsii. [Problems of especially dangerous infections]. 2007; 2: $24-27$ (in Russian).

16. Breneva N.V., Noskov A.K., Kiseleva E.Yu., Sharakshanov M. B., Borisov S.A., Kurganova O.P. et al. Analysis of the leptospiroses situation in Priamurie. Experience in a flooding zone in 2013 and the forecast for 2014. Probl. osobo opasnykh infektsii. [Problems of especially dangerous infections]. 2014; 1: $94-97$ (in Russian)

17. Breneva N.V., Kiseleva E.Yu., Makeev S.M. Problems of leptospiroses epidemiology and diagnostics in Siberia and at the Far East. Zhurnal mikrobiologii epidemiologii i immunologii. [Journal of Microbiology, Epidemiology and Immunobiology]. 2012; 3: 96 - 102 (in Russian).

18. Sharakshanov M.B., Breneva N.V., Noskov A.K., Kiseleva E.Yu., Vysochina N.P., Musatov Yu.S. et al. Current situation for leptospiroses in the south of the Far East. Epidemiologiya i infektsionnye bolesni. Aktualnye voprosy. [Epidemiology and Infectious Diseases. Current Items]. 2016 ; 4: 9 - 15 (in Russian).

19. Balahonov S.V., Popova A.Yu., Mishchenko A.I., Mikhailov E.P., Ezhlova E.B., Demina Yu.V. et al. A human plague case in Kosh-Agach district of Republic Altai in 2015. Report 1. Clinical-epidemiological and epizootological aspects. Probl. osobo opasnykh infektsii. [Problems of especially dangerous infections]. 2016; 1: 55 - 60 (in Russian).

20. Kutyrev V.V., Popova A.Yu., Ezhlova E.B., Demina Yu.V., Pakskina N.D. Shchuchinov L.V. et al. A human plague case in Gorno-Altai alpine natural focus in 2014. Report 1. Epidemiological and epizootological features of plague manifestations in Gorno-Altai alpine (Sailugem) natural plague focus. Probl. osobo opasnykh infektsii. [Problems of especially dangerous infections]. 2014; 4: 9 - 16 (in Russian).

21. Meshcheryakova I.S., Dobrovolsky A.A., Demidova T.N., Kormilitsyna M.I., Mikhailova T.V. Transmissible epidemic tularemia outbreak in Khanty-Mansiysk in 2013. Epidemiologiya i vaktsinoprofilaktika. [Epidemiology \& Vaccinal Prevention]. 2014; 5:14 - 20 (in Russian).

22. Ostapenko N.A., Solovieva M.G., Kazachinin A.A., Kozlova I.I., Faizullina N.M., Ezhlova E.B. About tularemia flash among the population of Khanty-Mansiysk town and Khanty-Mansiysk region in 2013. Probl. osobo opasnykh infektsii. [ ]. 2015; 2: 28 - 32 (in Russian).

23. Safeguarding of sanitary-and-epidemiologic well-being of the population at liquidation of consequences of flooding in the Far East. Edit. G.G. Onishchenko and S.V. Balakhonov. Novosibirsk: Nauka-Center; 2014 (in Russian).

24. Noskov A.K., Balakhonov S.V., Mikhailov L.M., Vishnyakov V.A., Kulikalova E.S., Mazepa A.V. et al. Epidemiologic situation on zoonotic infectious diseases on the territories of Siberia and Far East suffered from natural disasters in 2013 - 2014. Dalnevostochnyi zhurnal infektsionoi patologii. [Far Eastern Journal of Infectious Pathology]. 2016; 30: 6 - 10 (in Russian). 